\title{
Ethnic Acceptance Issues amongst Sabah and Sarawak Ethnic Groups at Sultan Idris Education University
}

\author{
Khairul Azam Bahari, Samsudin Suhaili, Norliza Jamaluddin, Kalsum Umar, Zulkarnin \\ Zakaria
}

\begin{abstract}
Students enrolment toUPSIbring alongdifferences in various background aspects which includeethnic-related issues andpublic acceptancetowards such differences. These differences could create a few unintended problems such as discrimination, isolation, stereotypingandethnic conflictthat could threatthe nationalunityas it could alsodirectly affect students' academicperformance.Currentresearchon multicultural problems in public universityhad not explored the issue seriouslyandmanymainlyfocused onmajorethnic groups in the country - Malay, Chineseand Indian. Meanwhile the study on other ethnic groups from Sabah and Sarawak in public universities has not received enough attention. Thus, this study was conducted to examine issues in relation to the acceptance ofotherethnicgroups from Sabah and Sarawak among the undergraduates of UPSI. This studyapplied the mixedmethodologyofqualitativeandquantitative approach. Data was collected using survey, interview, Delphi survey and simulation. Findings showed that there are many loopholes that need to be fixed by the management of UPSI in helping the students community understand the diversityofotherethnicgroups originating from Sabah and Sarawak. Theuniversitymust take the initiative to develop a mechanism that would help expose the campus community to embrace inter-culturalcommunication in a positive way. The study also found the need to reduce prejudice, stereotyping and discriminative attitude towards the ethnic groups from Sabah and Sarawak.
\end{abstract}

Keywords:multiculturalism, ethnic groups, Sabah, Sarawak, andpublicuniversity

\section{INTRODUCTION}

Malaysia is a melting potconsisting of multi-ethnic communities who live peacefully in this country.InMalaysia,the word ethnicrefers to a specificracethat has an important connotation on social and political aspects (Andiel, Matilda, Philip \&Gaik, 2009).

Revised Manuscript Received on June 22, 2019.

Khairul Azam Bahari, Fakulti Bahasa and Komunikasi, Universiti Pendidikan Sultan Idris, Malaysia.

Samsudin Suhaili, Fakulti Sains Kemanusiaan, Universiti Pendidikan Sultan Idris, Malaysia.

Norliza Jamaluddin, Fakulti Bahasa and Komunikasi, Universiti Pendidikan Sultan Idris, Malaysia.

Kalsum Umar, Fakulti Sains Kemanusiaan, Universiti Pendidikan Sultan Idris, Malaysia.

Zulkarnin Zakaria, Kolej GENIUS Insan, Universiti Sains Islam Malaysia
The multi-ethnic relationship requires a strong national unity among the multiracial and multi-religious communities because it involves a highly complex connection and needs some time to produce the desired results (SamsudinSuhaili, 2011). The diverse cultural backgroundin the Malaysian contextwas the result of the colonials' meddling in local administration especiallyduringtheBritish reign.

As a consequence, the British colonialhadcreatedan added value in societies' polarisation andthe way of lifeinthe Peninsula before the independence. The community's dynamic started to changewith the presence of other ethnics as it became more diverse than before.

A society with different culture, interracial understanding and a strong unity has to be built so that each ethnic with its own unique culture, language, religion, and belief can live in toleration and harmony. The peace of a nation will depend on the unity of the people that do not face any ethic problems or discrimination. To achieve this goal, various proactive measures had beenimplemented by the early governmentafter achieving the independence in 1957.

According to Rozita Ibrahim, Nazri Muslim andAhmatHidayat (2011), Malaysia aftertheindependencehad experienced interracial problems caused by socioeconomicimbalancebetween the Bumiputeraandnon-Bumiputeraresultingin a dark episode for the country with the interracial clashes on May 13, 1969. Racial unity is still a dream haunting the nation and is affecting the effort to establish the country as a peaceful plural society. Thus, the black dots in the country's otherwise peaceful timeline should serve as a reminder to the young generation to ensure the existence ofmulticulturalismamong the Malaysian communityisunderstoodandupholdwholeheartedly.

\section{Background of research}

Multiculturalismis a termwidely used in academic context and other related fields (Watson, 2002, hal. 3). In this study, multiculturalism deals with complex issues regarding the diversity of culture and religion in a specific society and the social management that was resulted through the challenges and opportunities by the multicultural situation itself (Nye, 2007, hal. 110). Nye's opinionwas supported by Hall (2000) who claimed that multiculturalism was used as an adjective to refer to characteristics and problems on its governance resulted by a society that has communities with different 
culture and religion living together, and each is trying to maintain their identity. The concept of multiculturalism exists in various countries such as Australia, the United States, Singapore, the United Kingdom, New Zealand, China, Indonesia, South Africa andother countries that have apluralsociety (Knight, 2008; Andiel, Matilda, Philip \&Gaik, 2009; Berkes, 2010).

Racial harmonyin Malaysia has been acknowledgedas an exampleto other countries in the world. Malaysia has almosteightyethnic groups, consisting of three main races of Malay, Chineseand Indian, including the indigenous people of Sabah and Sarawak. Even as a small nation, Malaysia has proven to the world that harmony is well and alive for more than 58 years in this country. Occasionally, the country would still encounter some fiery sparks in the effort of maintaining its peace. If preventive measures are not taken, there will always be risksthat could trigger the repeat of May 13, 1969 incidence.

\section{Multiculturalism in Malaysia}

Political development in Malaysia before, duringandafterthe independence has created aplural society withmulti-racial, cultural, and religious background. RosmanandKassim (2008) noted that historical factors played many roles in creating the multifaceted community caused by foreign labour migration that led to the pluralistic nature of the people.During the British colonialism, many Chinese and Indians from their homeland were brought into this country to cover the labour shortage at the time. The presence of other races from other countries had indirectly formed the multiracial identity for this country. It was obvious that multiracial and multicultural communities had inhibited this place even before the independence.The pluralistic society with its multiracial, religions and customs had always been part of this country but thehighlevel of toleration among the people was maintained successfully. At the same time, all the racesstill preserved their own identity without being influenced by the culture of other races.

Since independence, Malaysian community has been living in harmony. The positive environment in the country had proven to be a success to the nation and race. The success was achieved in various sectors such as economics, politicsand social. The economic sector covered main areas such as finance, trades, share market and business. Theseessentialsgeneratedthe nation's incomethatcomprised oftheimport andexportbusinesseslocally and overseas. Allraces had played their part in building the nation's economy. The generated income was used to develop this country over the years. Without the income from this sector,the country would easily collapse and be in chaos. Socially, the nation needs a peaceful and unitedsociety.Lacking this positive attitude would spell danger and trigger the ripple effect that would jeopardise the society's balance.

In the context of this study, multiculturalism born in Malaysia has always been referred or defined as ethnic or religious pluralism (Ahmad Tarmizi, Sarjit, Jayum, Zaid Ahmad \&NurAyuni Isa, 2012). Malaysia is a developing country located in Southeast Asia andis made of a population of people from mixed races,religionsand culture. For the period of 30 years, between 1980 and 2010, an

increaseandmodificationtotheMalaysian

residence compositionhad occurred drastically. In 1980, Malaysia had a population of only 13.7 million people. This number increased to 20.3 million people in the year 2010 (Statistic Department of Malaysia, 2010). Inthe year 2015, the Malaysian residence had reached 30.99 million people, and 31 million for the round figure. From this number, there were 19.2 million (62\%) bumiputerathat comprised of the Malay, Sabah and Sarawak ethnic people. The Chinese ethnic were 6.6 million (21\%) people, followed by the Indians who made up 2 million $(6 \%)$ people, other ethnics with 271 thousand $(0.9 \%)$ andforeigners who stood at 3 million (10\%) people.

\section{Multiculturalism in Institutions of higher learning}

Rosmida (1999) regarded university students as the agent of changein community. The group of students could bring a new idea that would encourage people to think. The university students in Malaysia are the priority in higher education. The development of higher education in Malaysia had gone through massive transformation in the multicultural aspect among its students (Rozita Ibrahim, Nazri Muslim andAhmatHidayat, 2011). This transformation can be seen through the historical development of higher education in Malaysia with the intake of students from various ethics.

From the historical aspect of higher education in Malaysia, there were three parts of development - the first era during the colonial time until the independence; the second, after the dark incident of May 13, 1969; andthe third, the current globalised era. All the three phases had changed the Malaysian higher education landscape and left a deep mark in shaping a strong ethnic relation in this country.

In the first phase - during the colonial time until the Independence, the higher education was not given the focus and only local who could converse in English would get a place to study in Singapore or be registered in matriculationatuniversities in Hong Kong or Britain(Abdul Rahman Ismail \&Mahani Musa, 2010). In addition, higher education during that time was using English as the medium of instruction and the use of Malay language was limited to a few universities or training centres at that time. From multicultural Polaview Point of view, the establishment of Universiti Malaya in Singapore hadappointed four Pro Chancellors from different ethnic background - High Commissioner of Malaya, Chief Governor of Singapore, Sir Han Hoe Lim andDato' OnnJaafar. This showed the involvement of Dato' OnnJaafarS a as a Pro Chancellor had given the opportunity to all races to study in higher education (Abdul Rahman Ismail \&Mahani Musa, 2010). Meanwhile, the establishment of Universiti Malaya in 1959 in Kuala Lumpur after the independence had opened the flood gate for Malaysians to have the chance the study at tertiary level.

In the second phase, it covered the duration after the bloody incidence of May 13, 1969. After the unfortunate event, triggered by the economic imbalance between the Bumiputeraandnon-Bumiputera, higher education was a 
major hope to unite the people and improve the situation (ZailanMoris\& Sh. Azad, 2010, hal. 1-36). The New Economic Policy (NEP) introduced the quota system for university intake to ensure the balance in ethnic composition of university students (Selvaratnam, 1988). Besides that, the Malaysian government had also established InstitutTeknologi MARA (ITM) in 1967 to secure the chance for the Bumiputera students to continue their study. The national language is a vital component in securing the ethnic integration andpromoting national identity. Thus, the Malay language had been chosen as the medium of instruction at institution of higher learning as the language of unity. According to Selvaratnam (1988),theBumiputerafavouritism policy did not sit well among the Chinese, but Brown (2007) claimed that the Chinese were generally not happy with the unequal government treatment to other ethnic minorities at the time. At the end of 1980, theMalaysian higher education sector had gone through changesandby that time, it was already offering equal opportunities to all students regardless of their socioeconomic background even with the quota system still in place. From the year 1980 until 1990, more public universities had been established to offer more places for all the ethnics (ZailanMoris\& Sh. Azad, 2010).

The third phase is the current globalised era that witnesses the role of higher education being linked to Post-industrial economy that involve productivity in science, technology and administration (Lee, 2004). Therefore, all universities in the world are now focusing on such objective. The main aim now is to develop the corporate culture and practice among the graduates to enable them to compete in the highly competitive job market.

Based on the discussion above, the nation's development and racial unityamong the university students of different ethnics would bode well for the future of nation-building of the country. However, the story on the ground did not reflect the painted picture,as seen among the students of Malaysian universities (Shamsul, 2010). A study by two local scholars proved that polarisation among the Malays andnonMalaysexisted(Sanusi Osman, 1984) andanother research by Abdul Samad (2003) found that 80\% students still had prejudice towards other ethnics.

Even though multiculturalism depicts a positive relationship among the ethnics, many students still feel awkward to spend time with friends of other ethnics in social activities such as dining together, study group, and especially sharing their living space for security reasons (Rozita Ibrahim, Nazri Muslim \&AhmatHidayat, 2011).

\section{Statement of the problem}

In a globalised world today, every level of education including the institutions of higher learning paysseriousattentionin acknowledging multiculturalismin the communityand the complications that affectits undergraduates (Burke, 2012).Their existence of various culturein the community are directly related to the need of the students and their life in university. With different social and cultural background, Quayeand Harper (2015) believed that students have to accustom themselves to their multicultural surrounding that would prove to be difficult if it is not understood and practiced positively.
To be accepted in a social environment while trying to be successful in facing the cultural clatters in university, isa challenge one has to deal with other than the usual expectation of academic excellence.Both goals are interrelated but dealing with multicultural problems proves to be the determining factor in securing one's academic excellence (Burke, 2012; Morgan, 2013). Hence, understanding the multicultural problems faced by a student has become an utmost importance for the university so that the problems could be dealt objectively before a strategic framework could be developed to cater to this issue (Benson, Heagney, Hewitt, Crosling\&Devos, 2013).

For Banks (2004), studying at an institution of higher learning, one cannot escape various multicultural issues and limitations such as language, religion and belief, gender, socioeconomic, mental and physical differences. These problems, if not managed holistically, could cause many negative effects whichaffectone's personal development. To supportGunawardenaand Wilson (2012), a student's moral development, social skills and even personal management and academic achievement throughout his studycouldbe affected if the issues are not well-managed.

Consequently, multicultural issues among university students should be studied and analysed. By establishing the knowledge and understanding on this aspect, higher education in university will be more successful in cultivatingstudents' personality and producing a responsible member of society who would also be asensible citizen (Zailan Morris \& Azad, 2010). In support of thisbelief, Lindsay, Beverly andBlanchett (2011) andsupported by Ahmad Hussein (2012) opined thatsuch a concerted effort wouldbreedstrong-minded university studentswithpositive personality,strong love for the nation,excellentmental and intellectual ability, andhigh social skills.

Based ontheCorevalue1 and 2 of the National Strategic Planning for Higher Education 2020 (PSPTN), it was clear that the Ministry of higher education aims to createaconduciveand functional teaching and learning environment in all campus. It would cover the preparation of educational infrastructure and financial support for those studying in institutions of higher learning. However, there are various issues that have to be solved which include socioeconomic divide, ethnic, religion and language. Other than that, the mental intelligence and physical ability between genders have to be taken into account (Banks, 2004). Subsequently, multi-cultural problems in university students' survival should be addressed seriously.

The step to identify objectively the problems and needs of multicultural students, together with the actions to overcome it is a worthwhile form of investment. Students willthen be able to benefit from the solutions to solve the multicultural differences so that they can focus on theirstudy.As a consequence, both the performance of the students and university would greatly improveand directly enhance the higher education rating of the nation (Morgan, 2013).

Other than that, due to its wide scope of study, the researchers decided to choose UPSI to carry out the research. 
This was obvious since UPSI is one of the universities with students ofdiverse multicultural background.Multiculturalism in UPSI has changed the campus landscape and this has presented a great opportunity for the researcherstostudymulticultural and adjustment issues among the students of UPSI.

\section{Research Objectives}

The general aim of this study is to examine and uncoverthevariousissuesinamulticulturalcampus community among the ethnic groups from Sabah and Sarawak inUniversitiPendidikan Sultan Idris (UPSI).

This study was conducted for these specific objectives:

1. to reviewissuesonethnicacculturationamong the Bumiputera ethnics from Sabah and Sarawak in UPSI.

2. to analyse the effect of ethnic differences in influencing the performance of a studentofotherBumiputeraethnic from Sabah and Sarawak in his/her study in UPSI.

\section{LITERATURE REVIEW}

Most of the references in this study were books that covered the subject, academic journals and research seminar. Generally, the academic world including higher institutions demand the acknowledgement on multiculturalism and its challenges facing the community. Students are directly affected by its various issues as they deal with the consequences of living in such a diverse campus community.The social and cultural difference force them to acquaint themselves with the surrounding and the challenging nature of such a diverse culture (Quaye\& Harper, 2015).

\section{Multiculturalism}

Research byMohd Amar (2013) had focused on the level of prejudiceand stereotyping among multi-ethnic pupils in secondary school in Malaysia. The study involved schools in Perak, Penang and Selangor. A few theories have been formulated, and a total of 1304 respondentswere involved and it consisted of Malay, Chinese, and Indian students of form 1, 2 and 4 who had been chosen to answer the survey. The findings showed that there was no significant difference in students' prejudice and stereotype construct based on gender, ethnic, type of primary schoolandlevel of form.

Noraini, MohdAderiandMohd Isa (2014) shared a few points in their research that covered the topic on multicultural elements in the teaching of Islamic studiessubject.The journal articlefocused on the importance of incorporating cultural elements in the teaching of Islamic studies and also identified the obstacles in implementing them in the teaching of the subject. The study utilized qualitative approach in the form of case study.The data was collected using interview and class observation. The outcome showed that through theintegrationofmulticultural elements, the concept of smart da'wah could be implemented easily. The control in discipline and increase in professionalism were evident in daily teaching practice.

An article written by MahzanArshad, Abdul JalilandNurfatimah (2011) explained on the appreciation or understanding about communities' values in a multicultural Malaysia accumulatedweredeveloped from various background. Italso discussed how the national education system had successfully increased the appreciation of multicultural values among the school students through the teaching of language andliterature.Education in multicultural society has helped the nation and its people to maintain their original language and culture.

The use of multicultural literature could close the gap in the societyforpeople of different race, social class, gender or physical disability. The exposure towards differences in culture and humorous elements, travel, language, and religion contribute to one's personal development, andcriticalthinkingthat would further promote an urbanised society who could thrive in the context of unity.

\section{Ethnic}

Ethniccould be defined as a group of people who followa standard culture. Theethnic group is referred to one's sociocultural heritage.It is also the group that practises its own socioculture.InMalaysia, Malay, Chinese, Indian,KadazanDusun, MelanauandIbanare also considered asethnic groups (Pue\&CharanjitKaur, 2014). The Malay, Chinese, Indian together with ethnic groups from Sabah and Sarawak have been living together for such a long time and they finally managedto create a unique Malaysian identity (MohdSohaimi, DayuSamsalu\& Budi Anto 2011). In reference to the figure shared by the Department of Statistics Malaysia (2015), other bumiputeraethnic groups in Sarawak were estimated to be $7 \%$ comprising ofKayan, Kenyah, LunBawang, Penan, Kelabit, Kedayan, Bisaya, Berawan, Lahanan, Sekapan, Kejaman, Penan, Baketan, Ukit, Sihan, Tagal, Tabun, Saban, Lisum, Longkiputandothers. For Sabah, it was estimated that $28 \%$ of its population was theotherbumiputeragroups known asKedayan, Bisaya, Irranun, Rungus, Kimarang, Kwijau, Lundayeh, Ubian, Binaand, Bugis, Tidung, Orang Sungai, Cocos, Lundayeh, Tatana, Tagaas, Brunei, Sulukandothers.

The definition of ethnicappearsintwodimensionswhich aresubjectiveand objective dimensions. Subjective dimension refers to the awareness of the presence of an ethnic identity, spirit of togetherness andmutualbenefit. On the contrary,objectivedimension focuses on similarities of cultural identities such as language, arts, clothes and customs which are shared together (Nazri Muslim, Faridah, Abdul Aziz, Mansor\&Kahirul Anwar, 2012). 
Table.1 Populationaccording to ethnic group, strata andgender, 2015

\begin{tabular}{|c|c|c|c|c|c|c|c|c|c|c|c|c|}
\hline \multirow{2}{*}{$\begin{array}{l}\text { Ethnic } \\
\text { Groups }\end{array}$} & \multicolumn{4}{|c|}{ Urban } & \multicolumn{4}{|c|}{ Rural } & \multicolumn{4}{|c|}{ Total } \\
\hline & Male & Female & Total & $\%$ & Male & $\begin{array}{c}\text { Femal } \\
\text { e }\end{array}$ & Total & $\%$ & Male & Female & Total & $\%$ \\
\hline $\begin{array}{c}\text { Bumiputer } \\
\text { a }\end{array}$ & $6,484.2$ & $6,401.9$ & $\begin{array}{c}12,886 . \\
1\end{array}$ & 56.0 & $\begin{array}{c}3,170 . \\
4\end{array}$ & $\begin{array}{c}3,094 . \\
3\end{array}$ & $\begin{array}{c}6,264 . \\
8\end{array}$ & 78.5 & $9,654.7$ & $9,496.2$ & $\begin{array}{c}19,150 . \\
9\end{array}$ & 61.8 \\
\hline Chinese & $3,134.9$ & $2,975.3$ & $6,110.2$ & 26.5 & 266.9 & 243.2 & 510.1 & 6.4 & $3,401.8$ & $3,218.5$ & $6,620.3$ & 21.4 \\
\hline Indian & 908.7 & 914 & $1,822.8$ & 7.9 & 83.8 & 82 & 165.8 & 2.1 & 992.6 & 996 & $1,988.6$ & 6.4 \\
\hline Others & 93.1 & 89.6 & 182.7 & 0.8 & 45.2 & 42.8 & 88.0 & 1.1 & 138.3 & 132.4 & 270.7 & 0.9 \\
\hline $\begin{array}{c}\text { Non- } \\
\text { Malaysian }\end{array}$ & $1,208.6$ & 804.9 & $2,013.5$ & 8.7 & 598.4 & 353.4 & 951.8 & 11.9 & $1,807.0$ & $1,158.3$ & $2,965.3$ & 9.6 \\
\hline Total & $\begin{array}{c}11,829 . \\
6\end{array}$ & $\begin{array}{c}11,185 . \\
7\end{array}$ & $\begin{array}{c}23,015 . \\
3\end{array}$ & $\begin{array}{c}100 . \\
0\end{array}$ & $\begin{array}{c}4,164 . \\
7\end{array}$ & $\begin{array}{c}3,815 . \\
7\end{array}$ & $\begin{array}{c}7,980 . \\
5\end{array}$ & $\begin{array}{c}100 . \\
0\end{array}$ & $\begin{array}{c}15,994 . \\
3\end{array}$ & $\begin{array}{c}15,001 . \\
4\end{array}$ & $\begin{array}{c}30,995 . \\
7\end{array}$ & $\begin{array}{c}100 . \\
0\end{array}$ \\
\hline
\end{tabular}

Source: Statistics Department of Malaysia (2015)

Table 1 shows the total number of people based on ethnic groups. The Bumiputeras are $61.8 \%$, the largest ethnic group.The second highest is the Chinese with $21.4 \%$. It is followed by the Indian with $6.4 \%$ andthe other raceswith 0.9 $\%$ andnon-Malaysian for $9.6 \%$. The table reflects thecleardistributionof the population based on ethnic and location of urban or rural areas.

The Malaysian societyhas not reached a maturity level that couldlabelthemselvesasa Malaysian race. In fact, the communities in this countryare toocomfortabletorely on the existing standards based on race, economics and politics that underline the racial discrimination. Malaysians still identify themselves as Malay, Malaysian-ChineseandMalaysianIndianignoring the fact that everyone belongs to the Malaysian race (ShamsulAmri, 2007).

\section{RESEARCH METHODOLOGY}

From micro point of view, studies on major problems in relation to ethnic cultural background were not done widely and detailed enough. Thus, as a form of exploratory and preliminary research, the Delphi approach is used to determine the suitability and need to deal withmulticulturalism among theundergraduates in this country.This method would help forming the experts' consensus on the major problems regarding the background culture of undergraduates of other ethnics in public universities (UA) clearly and in detail.Furthermore, this method is the most suitable to predict the multicultural need andadoptionfor students of other ethnics inUniversitiPendidikan Sultan Idris.

Delbecq, Van de Venand Gustafson (1975) specifically showed that the Delphi technique can be applied to achieve the following objectives:

$>$ To confirm or develop several alternative programmes.

$>$ To explore or expose assumptions or information that will lead todifferent propositions.

$>$ To obtain information that can produce agreement from a group of respondents.

$>$ To connect informed propositions on a broad discipline topic.
$>$ To educate a group of respondents on various aspects which are related.

Delphi technique is a suitable approach to achieve an agreement using a series of interviews to collect data from selected subjects(Linstone\&Turoff， 2002; Young \& Jamieson, 2001). In other words, the Delphi methodis unique in the process of collecting and analysing information that could lead tothe overall experience of the research participants. This method is different from other techniques because it utilises various measured which are designed to achieve the collective agreement on certain topics. Ludwig (1997), an explorer of Delphi method explained that:

Iteration refer to the feedback process. The process was viewed as a series of rounds; in each round every participant worked through a questionnaire which was returned to the researcher who collected, edited, and returned to every participant a statement of the position of the whole group and the participant's own position. A summation of comments made each participant aware of the range of opinions and the reasons underlying those opinions" (p. 55).

\section{FINDINGS AND DISCUSSION}

Respondents in the study acted as the expert group in a consensus agreed that there were serious problems and less serious ones onthecultural background faced by the groups of other ethnic inUPSI. This group of students assumed that the intake of Bumiputerastudents to the public universities was prioritised for the Malays andthey were not happy because there was no special opportunity given to other ethnics. They also felt that they were not given a fair share of attention and treatment while dealing with the administration office. They thought that they were almost treated as foreign students due the difference in culture Another obvious problem among the students was that they felt unsafe and worried because of other people'sprejudiceand negativity. 
These problems were consistent with the findings in the research byMarambaand Velasquez (2010) who claimed that students of ethnic minority were at a disadvantage when they were not given proper attention. They had to rely on the university to handle and settleany problem they had.Based on PueandCharanjit's (2014) research, it was stated that students from the ethnic majority displayed typical stereotypes towards the ethnic minority. This was quite common because of the number of students of the dominant ethnic that existed in the campus. Their big number encouraged the negative attitude that they displayed.

There are scepticism towards the different culture practised by the ethnic of Sabah and Sarawak. In fact, there was a feeling of injustice with the number of intakesamong the Malaystudents compared to the ethnics of Sabah and Sarawak. In their daily social life, there were respondents who felt isolated and decided to only mix with friends from their own ethnic. There was unfair treatment dished out by the university staff while dealing with matters in UPSI. Some even treated asforeignstudents due to the differenceinculture.Theminorityethnic groups was always misunderstood by the majoritygroupwhen they speak in their ethnic language especially among the bus driversinUPSI.

Table. 2ResponsestowardsEthnicIssues in UPSI

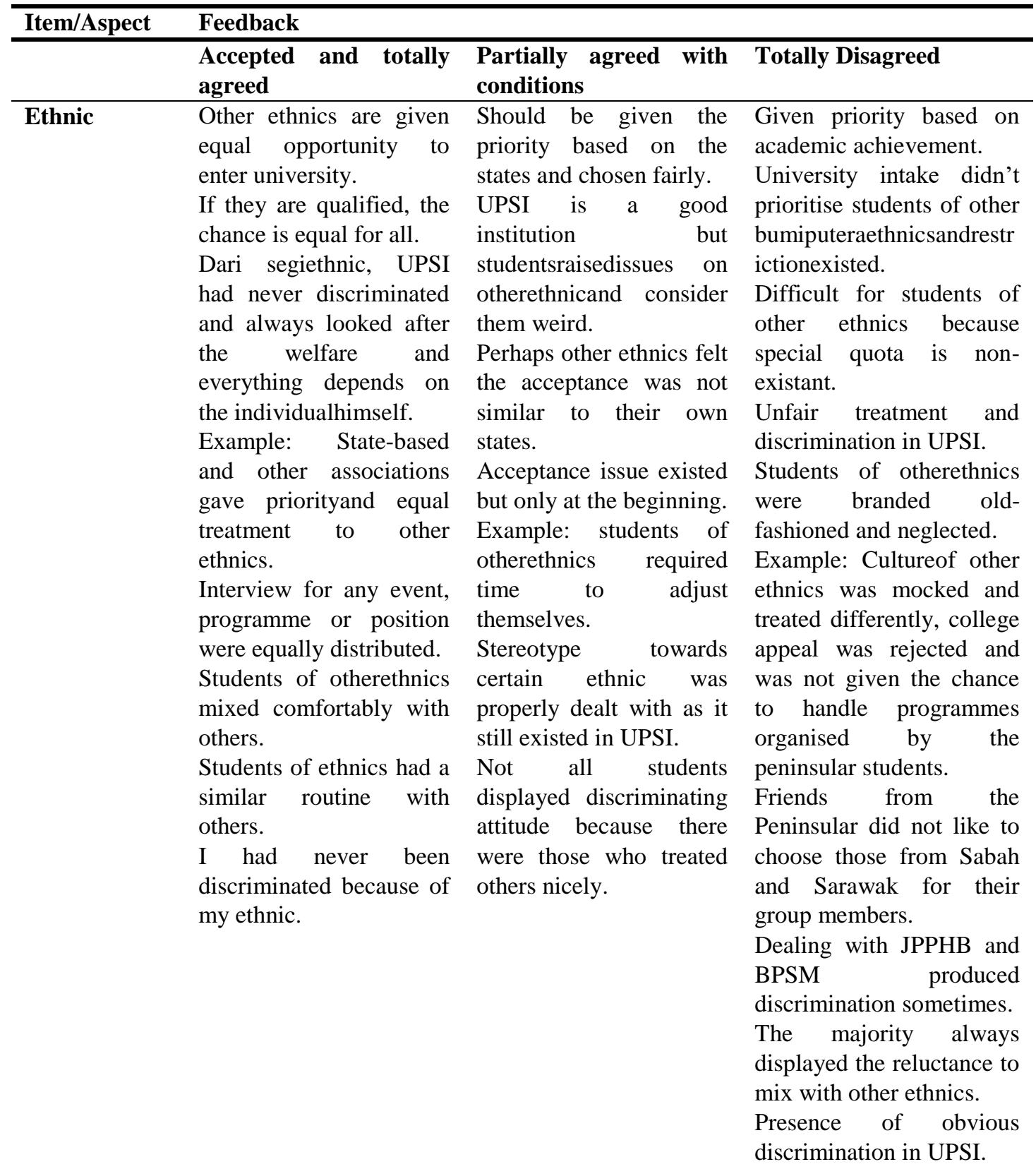




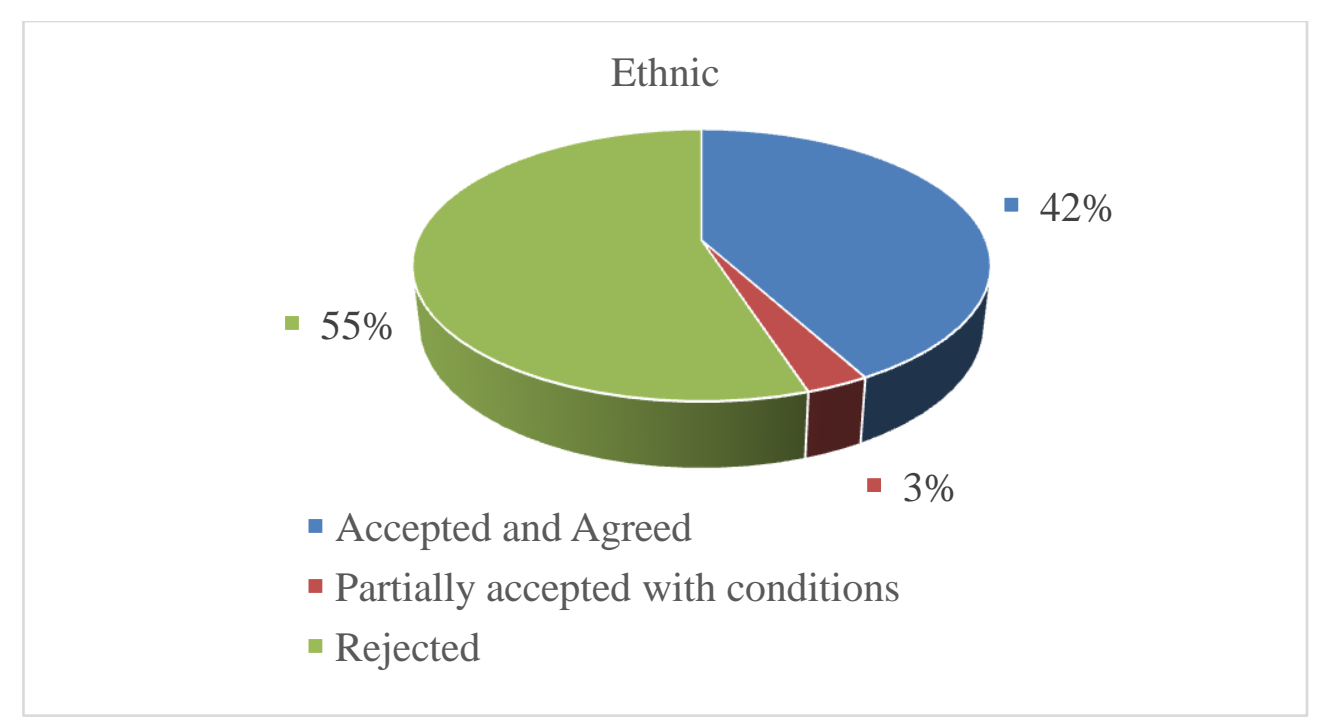

Fig. 1 Assessment and opinion towards ethnic component

From ethnic component point of view in a multicultural concept, Figure 1 showed42 students (42\%) fully accepted priority of other ethnics in public universities intakeandwere comfortable to talk about their cultural background to their friends in UPSI. Respondents also stated that UPSI had never discriminatedthem and always looked after the welfare of the students through the associations, programmes and many other efforts.Another42 students also agreed that they had never been discriminated because of their ethnic which had never been heard off in UPSI.

For the second category, only 3 students (3\%) had partially agreed with condition for every statement and the questions that had been asked in the ethnic component. The respondents felt that the intake of students from Sabah and Sarawak should be given priority according to the states and given equal treatment. They also agreed that UPSI is a good institution, but students like to raise ethnic issues regarding the differences in practice and culture that they considered peculiar. Respondents also stated that the acceptance and stereotyping factors should be abolished to avoid such problems in UPSI.

For the third category, more than half of the respondents thought there were problems in the form of ethnic acceptance andadaptationinUPSI. Total of 55 students (55\%) conceded that ethnic acceptance and adaptation was not well and agreed because of problems that exist.They believed that the students intake was chiefly based on academic qualification alone but not to the students other Bumiputeraethnics. The latter thought that there were restrictionsandchances were limited to the students from Sabah and Sarawak. They also felt that that they were looked down, considered old-fashioned, and their cultureandethnicwere mocked and discriminated in UPSI. Their peninsula classmates were even reluctant to choose them as their assignment partners.

Generally,more than half of the respondents considered that the students' composition in UPSI was not acceptedbyother ethnicgroupsin UPSI. They were some respondents who claimed that there was no such ethnic probleminUPSI.

\section{CONCLUSION}

Based on the findings in this study, the researchers can conclude three main approaches that can be implemented by the public universities, especially UniversitiPendidikan Sultan Idristo deal with issues related to the acceptance ofethnicsfrom Sabah and Sarawak. Among the recommendations is to create more space and opportunity for the students from Sabah and Sarawak to introduce their culture.This includes allocating a specific session in the orientation week that would help promote the culture and ethnicsfromSabah and Sarawak to all students. In addition, periodic activities can be organised by the students' affair, colleges and faculties.

Other than that, the University can also provide more holistic information about the different ethnic groupsfromSabahand Sarawak through various activities that can be planned specifically or generally for this purpose. Furthermore, to help increase the students understanding towards the other ethnic groups from Sabah and Sarawak, the academic centres in the university can offer various courses in inter-cultural communication to minimize the prejudice, discriminative, stereotyping attitude among the staff and students of UPSI.

\section{ACKNOWLEDGMENT}

The authors wish to express their gratitude and appreciation to the Research Management and Innovation Center, UPSI, for the research grant (Code: 2016-0160-106-01) that helped fund this research

\section{REFERENCES}

1. Abdul Rahman Ismail \&Mahani Musa. (2010). History of the growth and development of higher education in Malaysia until 2007. In ZailanMoris. (Eds.) \& National Higher Education Research Institute (Translator), 50 Years of Higher Education Development in Malaysia (1957-2007).(hal. 1-36). Pulau Pinang: PenerbitUniversitiSains Malaysia. 
2. Abdul SamadHadi. (2003). SenariosemasapelajarMelayu di IPTA. In S. Y. (Eds), IsuPencapaianPelajarMelayu(hal. 19). KualaTerengganu: Penerbit UMT.

3. Ahmad Hussein. (2012). Mission of Public Education in Malaysia: The Challenge of Transformation. Kuala Lumpur: University of Malaya Press.

4. Ahmad Tarmizi, Sarjit Singh, Jayum, Zaid,\&NurAyuni Isa (2012). Gagasan 1 Malaysia andImplikasinyaTerhadapPerhubunganAntaraEthnic. InstitusiPenyelidikan Pembangunan Belia Malaysia. Seminar KepimpinanandDasarNajib. UniversitiTeknologi Mara (UiTM). 13-25 September 2012.

5. Banks, J.A. (2004). Handbook of Research on Multicultural Education. San Francisco: John Wiley \& Sons.

6. Benson, R., Heagney, M., Hewitt, L., Crosling G. \&Devos, A. (2013). Managing and Supporting Student Diversity in Higher Education: A Casebook. United Kingdom: Chandos Publishing.

7. Berkes, L. (2010). The development and meaning of the concept of multiculturalism. International Relations Quarterly, 1(4), 1-6.

8. Brown, G. (2007). Making ethnic citizens: the politics and practice of education in Malaysia. International Journal of Educational Development, 27, 318-330.

9. Burke, P. J. (2012). The Right to Higher Education. Foundation and Future of Education. Abington, Oxon: Routledge.

10. Andiel P.S.G., Matilda, G., Philip, H., \&Gaik, C.K. (Eds) (2009). Race and multiculturalism in Malaysia and Singapore (pp. 240). London: Routledge.

11. Delbecq, A. L., Van de Ven, A. H., \& Gustafson, D. H. (1975). Group techniques for program planning: A guide to nominal group and Delphi processes. Glenview, Ill.: Scott, Foresman.

12. Gunawardena, H., Wilson, R. (eds.). (2012). International Students at University: Understanding the Student Experience. Switzerland: Peter Lang.

13. Hall, S. (2000). Conclusion: the multicultural question. In Hesse, B. (Eds).Unsettled Multiculturalism. (pp. 209-241). London: Zed Books.

14. JabatanPerangkaan Malaysia. (2010). Laporantahunanjabatanperangkaan Malaysia. Putrajaya: JabatanPerangkaan Malaysia.

15. JabatanPerangkaan Laporantahunanjabatanperangkaan Malaysia. Putrajaya: JabatanPerangkaan Malaysia.

16. Knight, K. (2008). What is multiculturalism? Griffith Working Papers in Pragmatics and Intercultural Communication 1(2), 106-118.

17. Lee, M. N. (2004). Global trends, national policies and institutional responses: restructuring higher education in Malaysia. Educational Research for Policy and Practice, 3, 31-46.

18. Lindsay, Beverly and Blanchett, W. J. (2011). Universiti and Global Diversity: Preparing Educators for Tomorrow. New York: Routledge.

19. Linstone, H.A. \&Turof, M. (2002). The Delphi method: Techniques and applications (versielektronik). Newark, NJ: New Jersey Institute of Technology.

20. Ludwig, B. (1997). Predicting the future: Have you considered using the Delphi methodology? Journal of Extension, 35(5), 1-4. Diambildaripada: http://www.joe.org/joe/1997october/tt2.html

21. MahzanArshad, Abdul Jalil\&NurfatimahAwang Da (2011). Peranankesusateraanpelbagaibudayadalampembentukanperpaduankeba ngsaan di Malaysia. Selangor: Universiti Malaya.

22. Maramba. D. \& Velasquez. (2010). Influences of the campus experience on the ethnic identity development of students of color. Education and Urban Society, 20, 1-24.

23. Mohd Amar Ibrahim Prejudisandstreotaipdalamkalanganmuridpelbagaiethnic Summit on Education 2013, 1011-1022.

24. MohdSohaimiEsa, DayuSamsalu, Budi AntoMohdTamring. (2011). Hubunganethnic: kelangsunganpembinaannegarabangsa. Selangor: Multimedia Sdn Bhd.

25. Morgan. (2013). Supporting Student Diversity in Higher Education. London: Routledge.

26. Nazri Muslim, FaridahJalil, Abdul Aziz Bari, MansorMohd Noor $\begin{array}{lll}\text { \&Khairul Anwar } \quad \text { Mastor. } & \end{array}$ Tahappenerimaanpelajarterhadapperuntukan orang Melayudalamperlembagaandariperspektifhubunganethnic di Malaysia. JurnalKemanusiaan, 18, 106-125.

27. Noraini Omar, MohdAderiChe Noh \&Mohd Isa Hamzah. (2014). KepelbagaianelemenbudayadalampengajaranPendidikan

Islam:
Isuandkepentingan. The Online Journal of Islamic Education, Special Issue, 1-12.

28. Nye, M. (2007). The challenges of multiculturalism. Culture and Religion. Interdisciplinary Journal 8(2), 109-124.

29. Pue, G.H. \&CharanjitKaur. (2014). Identitiethnicminoriti di Malaysia: antararealitisosialtafsiranautoritiandtafsiranharian. Akademika, 84(1\&2), 57-70.

30. Quaye, S.J. and Harper S. R. (2015). Student Engagement in Higher Education: Theoretical Perspectives and Practical Approaches for Diverse Population. New York and London: Routledge Taylor and Francis Group.

31. Rosman, M. Y., \& Kassim,

T. (2008). Teoriandpemikiranmengenaihubunganethnic. In Kassim, T. \&, Hamidah, A. R. (Eds).HubunganEthnic di Malaysia: Perspektif, TeoriandPraktik. (hal. 17-54). Skudai, Johor: Penerbit UTM Press.

32. Rosmida Abdul Rahman. (1999). 'Kembalikan Student Power'. Kuala Lumpur: MajalahTamadun.

33. Rozita, I., Nazri, M., \&Ahmat, H. (2011). Multiculturalism and higher education in Malaysia. Procedia Social and Behavioral Sciences 15 1003-1009.

34. SamsudinSuhaili.

(2011). Pendidikanpelbagaibudayaandpenerapannyadalamsistempendidikannas ional: aplikasipendekatan Delphi. Tesisijazahkedoktoran yang tidakditerbitkan. UniversitiKebangsaan Malaysia.

Sanusi Osman. (1984). Ikatanethnicandkelas.In S. H. (Editor), Ethnicity, Class and Development in Malaysia (hal. 79). Kuala Lumpur: PersatuanSainsSosial Malaysia.

35. Selvaratnam, V. (1988). Ethnicity, inequality and higher education in Malaysia. Comparative Education Review, 32(2), 173-196.

36. ShamsulAmriBaharuddin. (2007).ModulHubunganEthnic. Shah Alam: UPENA.

37. Shamsul, A. B. (2010). Islam embedded: religion and plurality in Southeast Asia as a mirror for Europe. In AnisYusalYusoff (Editor), Shamsul A.B. - His Observations, Analyses and Thoughts (pp. 146170). Bangi: InstitutKajianEthnic (KITA), UKM.

38. Watson, C.W. (2002). Multiculturalism. Philadelphia: Open University Press.

39. Young, S. J., \& Jamieson, L. M. (2001). Delivery methodology of the Delphi: A comparison of two approaches. Journal of Park and Recreation Administration, 19 (1), 42-58.

40. ZailanMoris\& Sh. Azad Sh. Attar. (2010). The Philosophy of Higher Education in Malaysia since Independence to the Present. In ZailanMoris. (Eds), 50 Years of Higher Education Development in Malaysia (1957-2007). (pp. 37-63). Pulau Pinang: Penerbit USM. 